\title{
Exotic garnet-clinopyroxene-K-feldspar granulites from the Chepelare shear zone, Central Rhodope massif, Bulgaria: implications for high-pressure granulite facies metamorphism
}

\author{
Milena Georgieva ${ }^{1}$, Tzvetomila Vladinova ${ }^{2}$ \\ ${ }^{1}$ Sofia University “St Kliment Ohridski”, 15 Tsar Osvoboditel Blvd, 1504 Sofia, Bulgaria; e-mail: milena@gea.uni-sofia.bg \\ ${ }^{2}$ Geological Institute, Bulgarian Academy of Sciences, Acad. G. Bonchev Str., Bl. 24, 1113 Sofia, Bulgaria; \\ e-mail: tsvetty@gmail.com
}

(Accepted in revised form: December 2019)

\begin{abstract}
Garnet-clinopyroxene-K-feldspar granulite occurs as a thick layer or boudin within the variegated rocks of the Chepelare shear zone in the Central Rhodope massif, Bulgaria. It consists of several domains: mesocratic homogeneous matrix (clinopyroxene-plagioclase-K-feldspar-quartz \pm amphibole), porphyroblastic garnet, K-feldspar and clinopyroxene, and strongly foliated fine-grained bands (chloritized biotitechlorite-prehnite-albite \pm epidote). The origin and nature of the matrix mineral association is still unclear. The peak porphyroblast association forms at the expense of plagioclase from the matrix at higher pressure. The fine-grained deformation zones channel the lattermost fluid infiltration. The clinopyroxene-garnet and Zr-in-titanite thermometry give temperatures higher than $790-860{ }^{\circ} \mathrm{C}$ at $2 \mathrm{GPa}$ and, with thermodynamic modeling, suggests crystallization at $\sim 1.8-2.1 \mathrm{GPa}$ and temperature of $\sim 850{ }^{\circ} \mathrm{C}$ in $\mathrm{HP}$ granulite field for the porphyroblast granulite association.
\end{abstract}

Georgieva, M., Vladinova, T. 2019. Exotic garnet-clinopyroxene-K-feldspar granulites from the Chepelare shear zone, Central Rhodope massif, Bulgaria: implications for high-pressure granulite facies metamorphism. Geologica Balcanica 48 (3), 49-63.

Keywords: garnet-clinopyroxene-K-feldspar granulites, HP granulites, granulite facies, Chepelare shear zone, Rhodope massif.

\section{INTRODUCTION}

Metamorphic complexes built up of variegated lithologies give a good opportunity to decipher the metamorphic history of orogens. Besides the wellstudied examples, protoliths with exotic bulk composition or with bulk composition affected by melt infiltration or metasomatic fluid-induced exchange of components are a challenge to metamorphic petrology and also bring insights into the metamorphic evolution of polymetamorphic terrains.

Characteristic features of many collisional orogens are high-pressure (HP) granulites that formed at the base of overthickened crust or as a result of subduction to mantle depths (O’Brien and Rötzler, 2003), and are related to periods of supercontinent amalgamation (Brown, 2007; Toutret and Huizenga, 2012). HP granulites are characterized by the key mineral assemblages of garnet-clinopyroxene-plagioclase-quartz in metabasic rocks and are kyaniteK-feldspar-bearing in metapelitic and felsic bulk rock compositions and typically orthopyroxene-free in both basic and felsic bulk compositions (O'Brien and Rötzler, 2003; Pattison, 2003; Brown, 2007). The plagioclase-free garnet-clinopyroxene assemblage indicates conditions in the transition zone between granulite and eclogite facies (Pattison, 2003). The mineral association garnet-clinopyroxene$\mathrm{K}$-feldspar is not common in granulite terrains. In a few cases from the literature, the association garnet-clinopyroxene-K-feldspar has been reported from intermediate granulites from the Bohemian massif (Racek et al., 2008; Štípská et al., 2014), retrogressed eclogite boudin from the Central Rhodope massif (Machev and Kolcheva, 2012), but also as a product of high-temperature hydrothermal altera- 
tion (Dziggel et al., 2009). The origin and mechanisms of its formation are different and still under discussion: crystallization from dry melt; diffusion or melt infiltration for the intermediate granulite; interaction of symplectites with melt from adjacent migmatic gneisses in retrogressed eclogite or alteration of calc-silicate rock by hydrothermal fluid. In all cases, the textures are complex and melt or fluid is present.

In this study, we present first data on the petrography, mineral chemistry and P-T conditions of formation of garnet-clinopyroxene-K-feldspar granulite from the Central Rhodope massif. We discuss the possible protolith and try to reconstruct the metamor- phic history of the variegated complex. The close spatial relationship of the studied sample with the diamond-bearing garnet-kyanite gneisses suggests a common metamorphic evolution and rising of temperature during exhumation and decompression after ultra-high-pressure (UHP) metamorphism.

\section{GEOLOGICAL SETTING}

The Rhodope massif is a part of the Alpine-Himalayan orogenic system and, in Bulgaria, it was subdivided into several lithotectonic units by Sarov (2012) (Fig. 1). The Rhodope massif evolution was

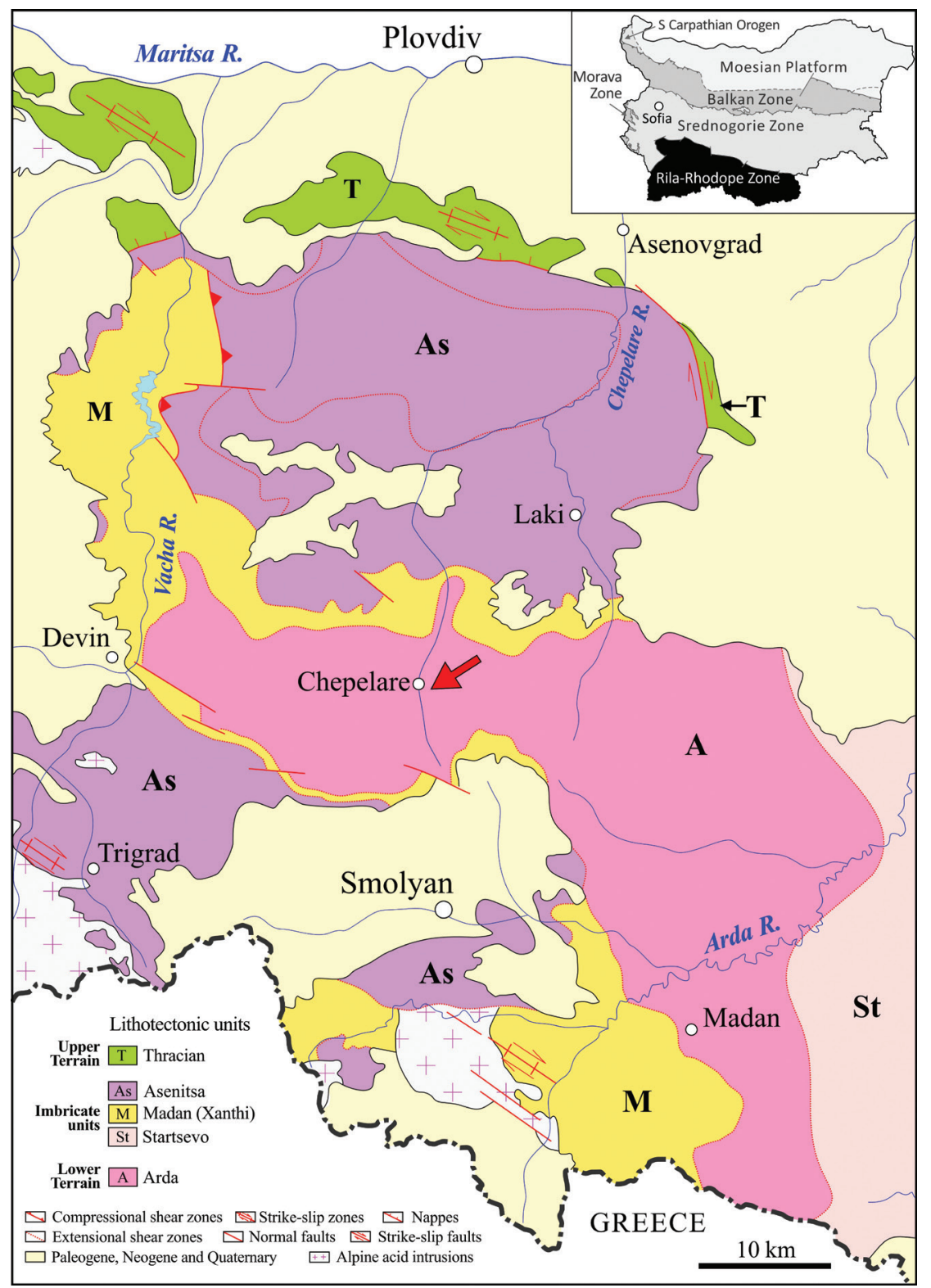

Fig. 1. Simplified geological map with lithotectonic subdivision of the Central Rhodope massif (after Sarov, 2012). The upper inset shows the main tectonic units on Bulgarian territory. The red arrow points to the study area. 
regarded as a nappe system of complex detachment structure (Burg, 2012, and references therein). Metamorphism and deformation are attributed to compressional, followed by extensional, regime in an exhumed metamorphic core complex (Ivanov et al., 2000). The variegated rock assemblage known as the Chepelare Formation (Ivanov et al., 1984; Kozhoukharov, 1984), Chepelare mélange or Chepelare shear zone (Gerdjikov et al., 2010) (Fig. 2) coincides with approximately 1-km thick zone of intense strain, previously interpreted as a synmetamorphic thrust of presumed Mesozoic age (Ivanov et al., 2000). However, recent data indicate that this strain was still active during the late Eocene (Gerdjikov et al., 2010).

The Chepelare shear zone (CSZ) is a well-defined structure within the orthogneisses of the Arda lithotectonic unit (Gerdjikov et al., 2010) and is characterized by mainly metasediment protoliths: pure and impure marbles, garnet-kyanite gneisses and schists, biotite or two-mica gneisses, garnet- bearing metabasites, small ultramafic bodies, and eclogite boudins. The recent findings of microdiamonds in garnet-kyanite gneisses from CSZ (Collings et al., 2016; Petrík et al., 2016) have confirmed an earlier UHP event and a more complex tectonometamorphic history of the rocks from the zone. The UHP metamorphism was followed by high-pressure granulite facies, as recorded by mineral assemblages in different lithologies from the zone (Cherneva et al., 2008a; Georgieva et al., 2007, 2010). Intensive amphibolite facies overprint (Cherneva and Georgieva, 2007) refers to Eocene metamorphism (Didier et al., 2014) and precludes the good preservation of former high-pressure assemblages. There remains significant disagreement among various authors on the timing of metamorphic events that affected the rocks from CSZ. The geochronological data come mainly from monazite U-Th- $\mathrm{Pb}$ isotope geochronology. Didier et al. (2014) analyzed monazites from a garnet-kyanite schist in the CSZ and the geochronological data defined two metamor-

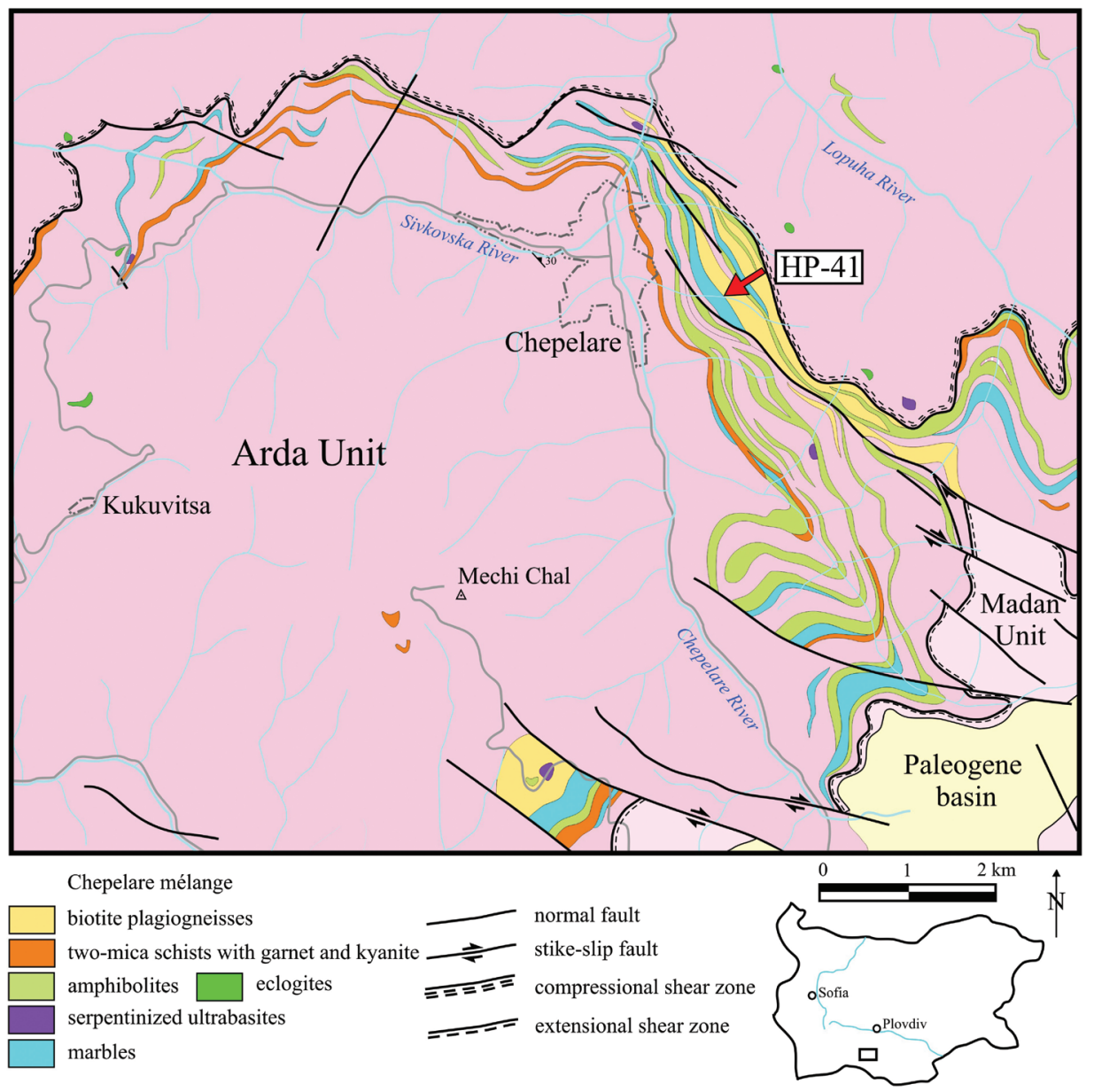

Fig. 2. Geological map of the studied area with main lithotectonic units shown after Sarov (2012). The rock types within the Chepelare shear zone are according to Sarov et al. (2006). Indicated is the location of the studied sample HP-41. 
phic events: dehydration melting in granulite-facies with age estimate, provided by the mean ${ }^{208} \mathrm{~Pb} /{ }^{232} \mathrm{Th}$ age and its standard deviation, of $138 \mathrm{Ma} \pm 10 \mathrm{Ma}$ (data range from $115 \mathrm{Ma}$ to $165 \mathrm{Ma}$ ) and mid-Cenozoic lower-grade fluid-assisted partial melting at ca. 36 Ma. Monazites from a garnet-kyanite gneiss analyzed by EMPA in situ yield older ages in the cores of ca. $200 \mathrm{Ma}$ and are interpreted as the timing of UHP metamorphism, whereas the younger age of Y-rich rims at $c a .160 \mathrm{Ma}$ was assigned to later granulite facies/partial melting overprint (Petrík et al., 2016). Much younger, Late Cretaceous is the time of the UHP metamorphism, defined by Collings et al. (2016) (70.5-92.7 Ma) based on garnet Sm-Nd isotope geochronology in the same rocks. Our geochronological U-Th-Pb isotope data (Georgieva et al., 2011) on zircons (126-136 Ma) and monazite (137-144 Ma) from produced by HP melting garnet-bearing leucocratic gneisses from the CSZ support the data of Didier et al. (2014) for a main high-grade metamorphic event during the Late Jurassic-Early Cretaceous times.

During the last decade, HP granulites and products of HP melting have been reported from several localities in the Rhodope massif (Machev and Kolcheva, 2012; Didier et al., 2014; Wawrzenitz et al., 2015), including a variety of lithologies from the CSZ (Georgieva et al., 2007, 2010, 2011; Cherneva et al., 2008a, 2008b; Petrík et al., 2016). We studied a garnet-clinopyroxene-K-feldspar granulite from the CSZ in an attempt to complete the data on the metamorphic evolution of the area and to reconstruct its P-T path. Mesocratic rocks with big garnet porphyroblasts (up to $1.5 \mathrm{~cm}$ ) crop out as single blocks or a thick layer in the southern edge of an abandoned Marble quarry to the east of the town of Chepelare (Fig. 2). In the southern part of the quarry's slope also crop out biotite gneisses and weathered schists, together with two thicker sub-horizontal amphibolite layers $(\sim 2 \mathrm{~m})$, well visible in the upper part of the quarry. The studied samples were found as huge blocks (Fig. 3a), while the outcrops are few and the information about the position and relationships of the studied samples regarding the other rock types is scarce. We found only a conformable contact of the granulites with weathered garnet-biotite schists (Fig. 3b), and it seems that the studied rocks form a thick layer (1-2 m) or boudin, subparallel to the foliation, in-between the two amphibolite layers or above the second amphibolite layer.

\section{PETROGRAPHY AND MINERAL CHEMISTRY}

The samples are foliated, with three distinct parts: a) mesocratic homogeneous matrix (clinopyroxene-plagioclase-K-feldspar-quartz \pm amphibole); b) lenses of porphyroblastic garnet, K-feldspar and clinopyroxene \pm plagioclase, amphibole; and c) strongly foliated fine-grained bands (chloritized biotite-chlorite-prehnite-albite \pm epidote and clasts of the other minerals, mainly clinopyroxene and amphibole) (Fig. 4, Table 1). The fine-grained bands are unevenly distributed and oriented at small angle towards the foliation, lightly banded along the porphyroblasts. Accessory minerals include titanite, allanite, zircon, apatite, rutile, pyrite, ilmenite, and other opaque minerals. Mineral chemistry analyses
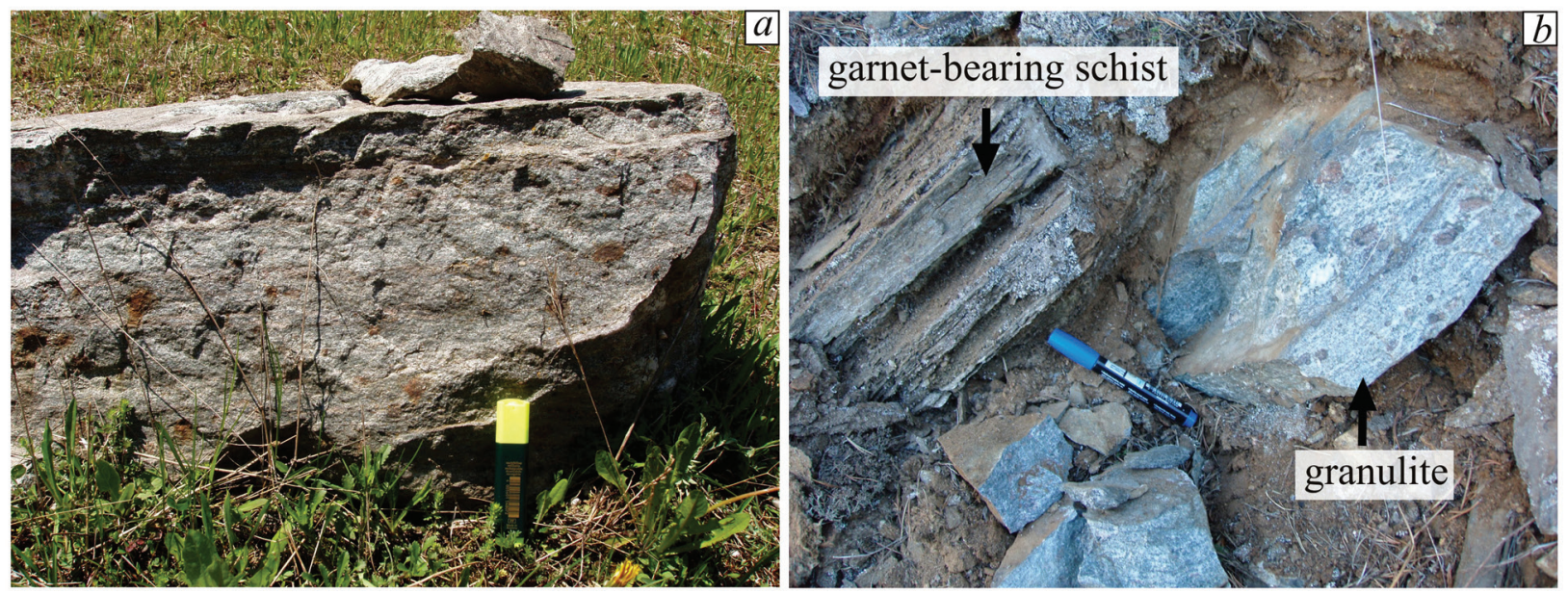

Fig. 3. Field photographs of the studied sample: $a$ ) a block of granulite (with size of $\sim 0.4 \times 1 \times 0.8 \mathrm{~m}$ ) in the abandoned marble quarry; $b$ ) one of the few outcrops showing the subparallel to the foliation boundary of the studied granulite with altered garnetbearing schists. 


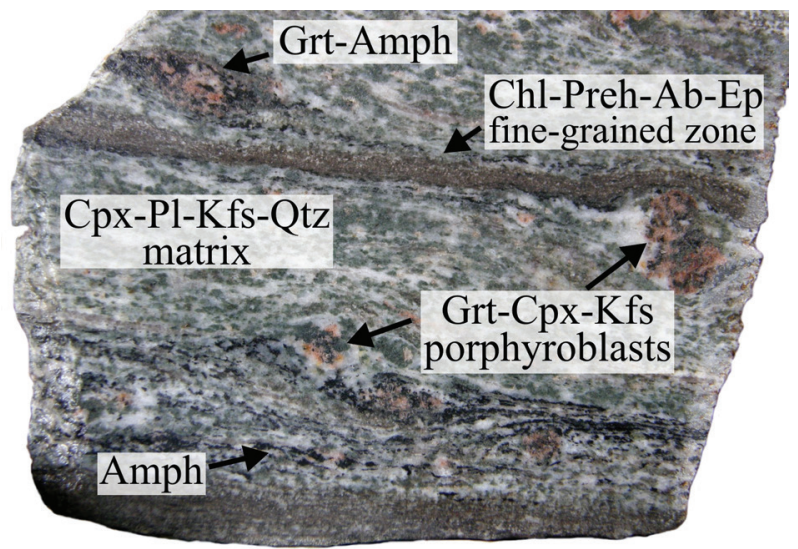

Fig. 4. Photograph of a hand-cut sample showing the different textural parts of the studied granulite: mesocratic matrix, porphyroblast association and fine-grained zones. The bottom side of the photograph is $10 \mathrm{~cm}$.

were performed by JEOL Superprobe-733 at the Geological Institute of the Bulgarian Academy of Sciences, at $15 \mathrm{kV}$ and $100 \mathrm{~s}$, with natural and synthetic standards.

Clinopyroxene and plagioclase are the predominant minerals in the homogeneous mesocratic matrix (Fig. $5 a, b, f$ ). Clinopyroxene is hypidioblastic and orientated along the foliation, weakly replaced by amphibole. In association with garnet and $\mathrm{K}$ feldspar porphyroblasts, the clinopyroxene forms big (up to $1 \mathrm{~cm}$ ) grains and the replacement by amphibole along the cleavage planes and rims is more intensive than the clinopyroxene in the matrix (Fig. $5 c-e$ ). In both cases, the clinopyroxene is diopside to hedenbergite (Morimoto et al., 1988) (Fig. 6). The jadeite content is up to $4.5 \mathrm{~mol} \%$, with highest values in the cores of porphyroblasts and big grains in the matrix (Appendix A). For some porphyroblasts, the Na content is higher in the core and lower or missing in the rim. Diffuse brighter outer zones, lighter shadows and close to inclusions of some big clinopyroxene grains in the matrix are enriched in Fe (XMg ranges from 62 to 45 ) and plot in the hedenbergite field. Based on composition, it is difficult to discriminate between the clinopyroxene from the matrix and the porphyroblastic one because of the variable composition related to diffusion at lower temperature in the matrix and control of available components during the crystallization of the porphyroblasts.

Plagioclase occurs in all parts of the sample and shows a huge variation in composition (Fig. 7; Appendix A). Anorthite-rich is the plagioclase in the mesocratic matrix, mainly labrador-bitovnite $\left(\mathrm{An}_{65-88}\right)$ (Fig. 5a, b, f) and, at the contacts with $\mathrm{K}$-feldspar, there is a weak myrmekitization. The plagioclase is scarce in the coarse-grain garnetclinopyroxene-K-feldspar part of the sample. In the coarse-grain parts, it associates mainly with garnet (Fig. 8a) and its composition varies significantly (oligoclase-labrador, $\mathrm{An}_{19-59}$ ). In both cases, the orthoclase compound in plagioclase is low (max $\mathrm{Or}_{1.7}$, average $\mathrm{Or}_{0.5}$ ). Albitizaton of the plagioclase is observed along the rims of the mineral grains (Fig. 5f) or as net, especially where epidotization is more intensive (Fig. $8 a, b$ ). In the late high-strained mica bands, the plagioclase appears as lenses with relict anorthite-rich central parts $\left(\mathrm{An}_{59}\right)$ and intensive albite $\left(\mathrm{An}_{7}\right)$ replacement to the rim (Fig. 8f). The plagioclase composition changes from bitovnite in the mesocratic matrix to oligoclase-labrador in association with the garnet. The coarse-grain minerals grew at the expense of plagioclase, outside its stability field. The decomposition of plagioclase causes an abrupt change of grossular content in the garnet and relatively enriched in $\mathrm{Na}$ in the central parts of the clinopyroxene porphyroblasts. The late albitization affects all parts of the sample but is most intensive in the fine-grained bands, where the albite associates with chlorite and prehnite.

The garnet appears as small angular grains or aggregates included or intergrown with clinopyroxene, K-feldspar and with later amphibole (Fig. $5 c, d$ ). In association with plagioclase, the garnet forms bigger porphyroblastic grains, as it seems that its crystallization started before the clinopyroxene and K-feldspar in the coarse-grain parts (Fig. 8a). Inclusions in the garnet are not common, mainly K-feldspar, epidote and pyrite. Garnet's composition is almandine-grossular dominated by high variation of all compounds:

Table 1

Mineral composition of different parts of the studied granulite

\begin{tabular}{lcccccccccc}
\hline Mineral composition & Grt & Cpx & Kfs & Qtz & Pl & Amph & Bt & Ep & Preh & Chl \\
\hline a) mesocratic homogeneous matrix & & $\mathrm{x}$ & $\mathrm{x}$ & $\mathrm{x}$ & $\mathrm{x}$ & \pm & & \pm & \\
b) lenses of porphyroblastic minerals & $\mathrm{x}$ & $\mathrm{x}$ & $\mathrm{x}$ & $\mathrm{x}$ & \pm & \pm & & \pm & \\
c) foliated fine-grained bands & & & $\mathrm{x}$ & $\mathrm{x}$ & $\mathrm{x}$ & \pm & $\mathrm{x}$ & \pm & $\mathrm{x}$ & $\mathrm{x}$ \\
\hline
\end{tabular}



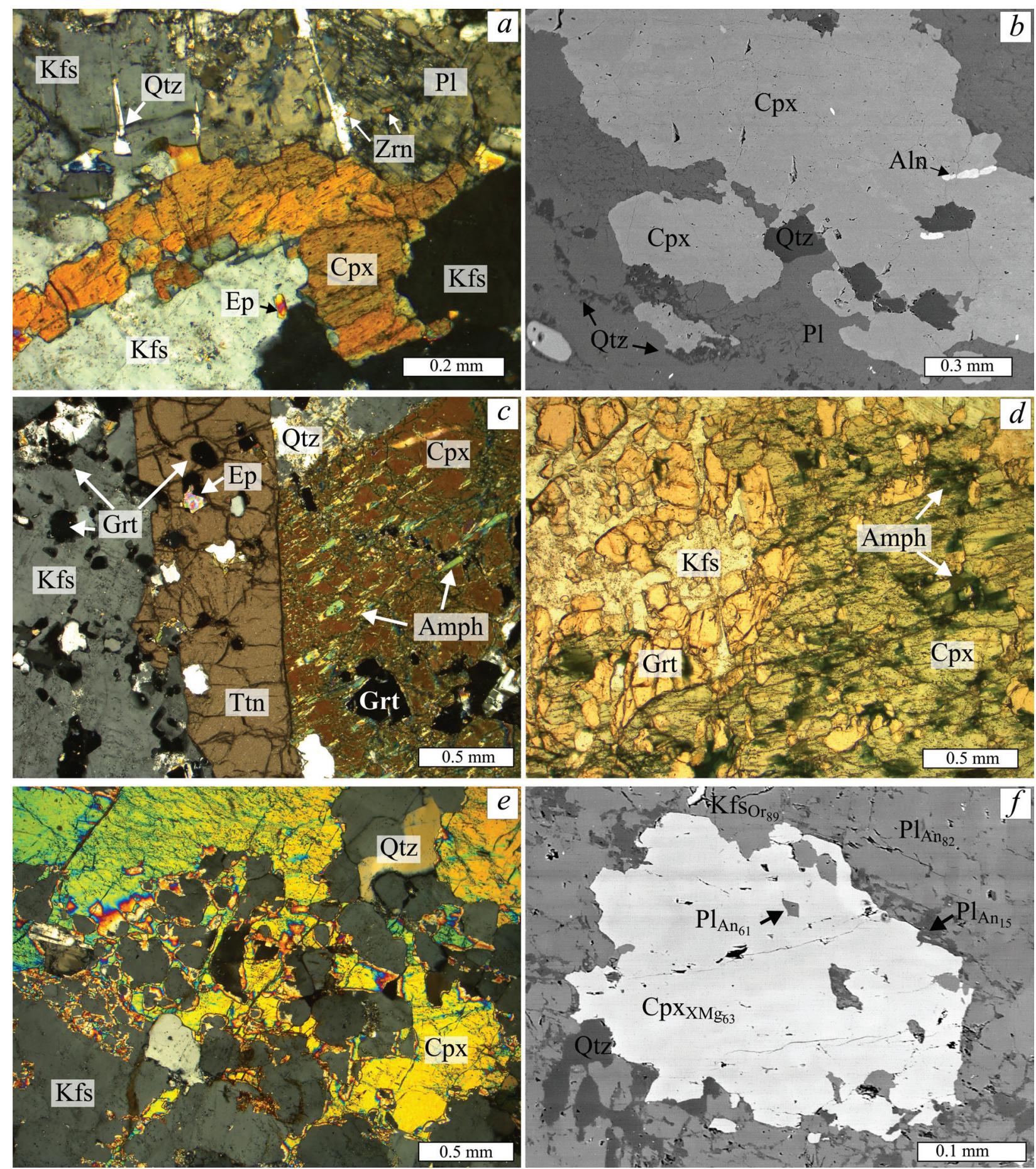

Fig. 5. Photomicrographs ( $a, c-e)$ and BSE images $(b, f)$ of the garnet-clinopyroxene-K-feldspar granulite: $a$ ) mesocratic matrix (cross-polarized light); $b$ ) mesocratic matrix with larger clinopyroxene subhedral grains; $c$ ) porphyroblast association of garnetclinopyroxene-K-feldspar and accessory titanite; the clinopyroxene is partly replaced by amphibole along the cleavage planes (cross-polarized light); $d$ ) porphyroblast intergrowths; the amphibole replaces garnet and clinopyroxene (plane-polarized light); e) anhedral clinopyroxene-K-feldspar intergrowth; the K-feldspar forms elongated interstitial grains or a net-like structure (crosspolarized light); f) mesocratic matrix with albitization of the plagioclase close to the clinopyroxene grain.

$\mathrm{Alm}_{38-62}, \mathrm{Grs}_{22-48}, \mathrm{Pyr}_{4-10}$ and $\mathrm{Sps}_{5-13}$ (Fig. 9a; $\underline{\mathrm{Ap}-}$ pendix A). Profiles in most of the garnet grains are weakly prograde or flat with no clear core-to-rim chemical zonation. We observed an abrupt change in composition when garnet porphyroblast passes into clusters of small hypidioblastic grains or fragments that intergrow with other porphyroblasts: from $\mathrm{Alm}_{60}, \mathrm{Grs}_{22}, \mathrm{Pyr}_{6}, \mathrm{Sps}_{12}$ to $\mathrm{Alm}_{47}, \mathrm{Grs}_{44}, \mathrm{Pyr}_{4}, \mathrm{Sps}_{5}$ 


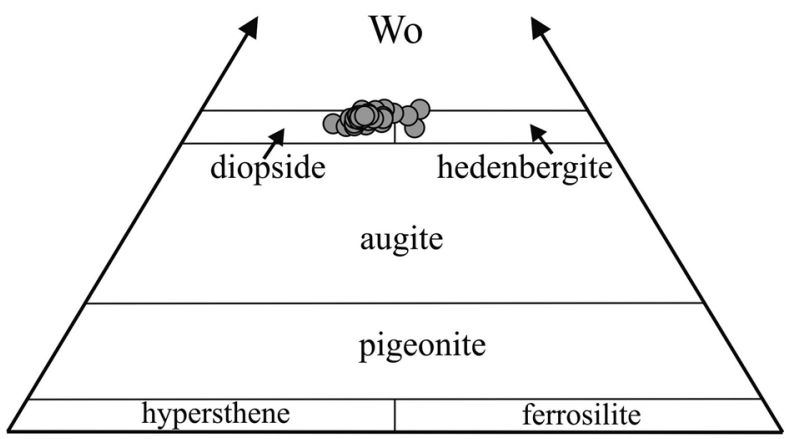

En

Fs

Fig. 6. Wo-En-Fs diagram of clinopyroxene from matrix and porphyroblastic association (after Morimoto et al., 1988).

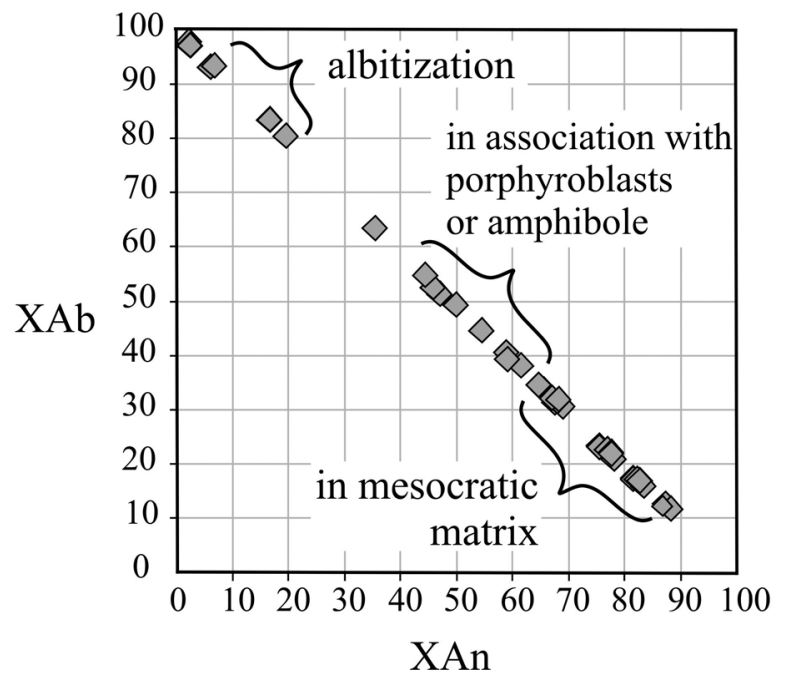

Fig. 7. Albite-anorthite plot of plagioclase composition from different mineral associations.

(Fig. 9b). This high variation in garnet composition is due to plagioclase decomposition and is controlled by change in grossular content. Almandine-type garnets are preserved in the inner parts of the porphyroblasts or where it associates with medium plagioclase (Fig. 8a). The higher grossular content suppresses all other compounds, reflecting in lower almandine but higher XMg ratio. Thus, in the sample, there are two groups of garnets: almandine-dominated in the central parts of some porphyroblasts and in association with plagioclase; and almandine-grossular garnets from the garnet-clinopyroxene-K-feldspar assemblage that form at the expense of plagioclase at higher pressure.

$\mathrm{K}$-feldspar occurs in the mesocratic matrix as elongated xenomorphic grains (Fig. $5 a$, f). With garnet and clinopyroxene, it forms big xenomorphic grains and intergrowths (Fig. $5 c-e$ ). K-feldspar contains inclusions of retrograde minerals (epidote, chlorite and opaques) (Fig. 8c). The orthoclase content ranges from $87 \mathrm{~mol} \%$ to $95.6 \mathrm{~mol} \%$, the albite content is up to $11.3 \mathrm{~mol} \%$, while the anorthite rarely exceeds 1 mol\% (Appendix A). K-feldspar contains lower values of albite and anorthite (4-5 mol\%) in retrogressed parts with epidotization and albitization (Fig. 8b). In the matrix and with porphyroblasts similar to clinopyroxene, the composition of the K-feldspar varies significantly. Highest is the albite content in porphyroblasts and cores of the big subhedral grains in the matrix. The albite content in K-feldspar is strongly controlled by the recrystallization of the Ca-rich matrix plagioclase, and formation of grossular-rich garnet-clinopyroxeneK-feldspar beyond the plagioclase stability field. Close to garnet porphyroblasts, smaller, weekly deformed K-feldspars form triple junctions.

Amphiboles in the mesocratic matrix form subhedral crystals, or a cluster of smaller euhedral grains usually conforms to the foliation and often appears close to the fine-grained deformation zones of the sample. Amphibole replaces the clinopyroxene along the cleavage planes (Fig. $5 c, d$ ) and fills the cracks or intergrowths with garnet (Fig. 8a). According to Leake et al. (1989), it is classified mainly as ferro-pargasite (less as pargasite, edenite and ferro-edenite), with XMg from 35 to 51 (Fig. 10). Although the amphibole is analyzed in different textural positions (i.e., as bigger grains in the mesocratic matrix, filling the cracks in garnet porphyroblasts or intergrown with garnet, or as smaller grains in the deformation bands), its composition does not vary significantly. Optically zoned amphibole grains in the matrix show rising from core-to-rim $\mathrm{XMg}$ (42-51) and $\mathrm{Al}^{\mathrm{VI}}$ (from 0.56 to $0.68 \mathrm{apfu}$ ).

Epidote occurs in all parts of the sample. It appears as small grains among the matrix minerals (Fig. 5a), fills the cracks in the garnet (Fig. 8a), is found as inclusions in garnet, clinopyroxene, titanite and K-feldspar or forms strands on plagioclase (Fig. 8a), but is also present in zones of epidotization (Fig. 8b). During the low temperature alteration, together with chlorite, pyrite and ilmenite, the epidote pseudomorphs other minerals (probably titanite) (Fig. 8c). The pistacite component ( $\mathrm{Ps}=$ $\left.\mathrm{Fe}^{3+} /\left(\mathrm{Fe}^{3+}+\mathrm{Al}\right) * 100\right)$ or XFe (sensu Armbruster et al., 2006) ranges from 26 to 0.4 , from epidote (30$15)$ to clinozoisite (15-0). Epidote associates with garnet, while the clinozoisite is related to feldspars (formed after plagioclase or occurs as inclusions in K-feldspar). Highly varying is the composition in zones of epidotization $\left(\mathrm{Ps}_{0.4-26}\right.$, Fig. $\left.8 b\right)$ or even 

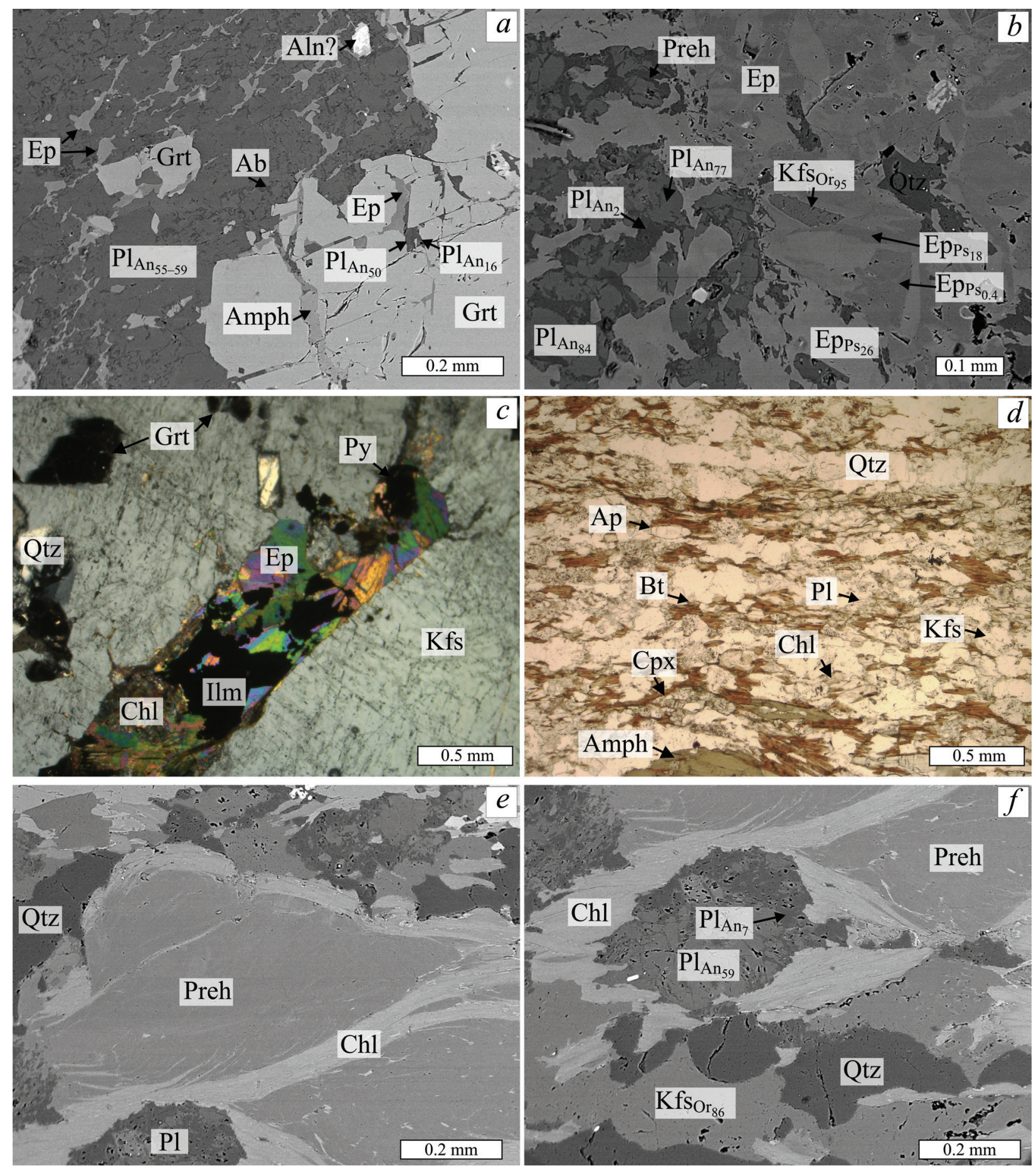

Fig. 8. Photomicrographs $(c, d)$ and BSE images $(a, b, e, f)$ of the garnet-clinopyroxene-K-feldspar granulite: $a)$ garnet in association with intermediate plagioclase; both minerals are partly replaced by albite and epidote; $b$ ) zone of intense epidotization and albitization with highly varying compositions of epidote-clinozoisite solid solution and plagioclase; $c$ ) pseudomorph of epidote, chlorite, pyrite and ilmenite after titanite (cross-polarized light); $d$ ) fine-grained deformation band (plane-polarized light); $e$ ) chlorite, albite and prehnite lens in the matrix; f) chlorite, albite and prehnite lens in the matrix.

in big euhedral epidote grains in the matrix with patchy zoning $\left(\mathrm{Ps}_{1-25}\right)$.

Biotite, chlorite, albite and prehnite are related to strongly fine-grained deformation bands (Fig. 8d) or lenses in the matrix (Fig. 8e, f). These zones localize the deformation and include stretched and reduced in size minerals, mainly from the matrix. Despite looking fresh in thin-sections, the biotite 

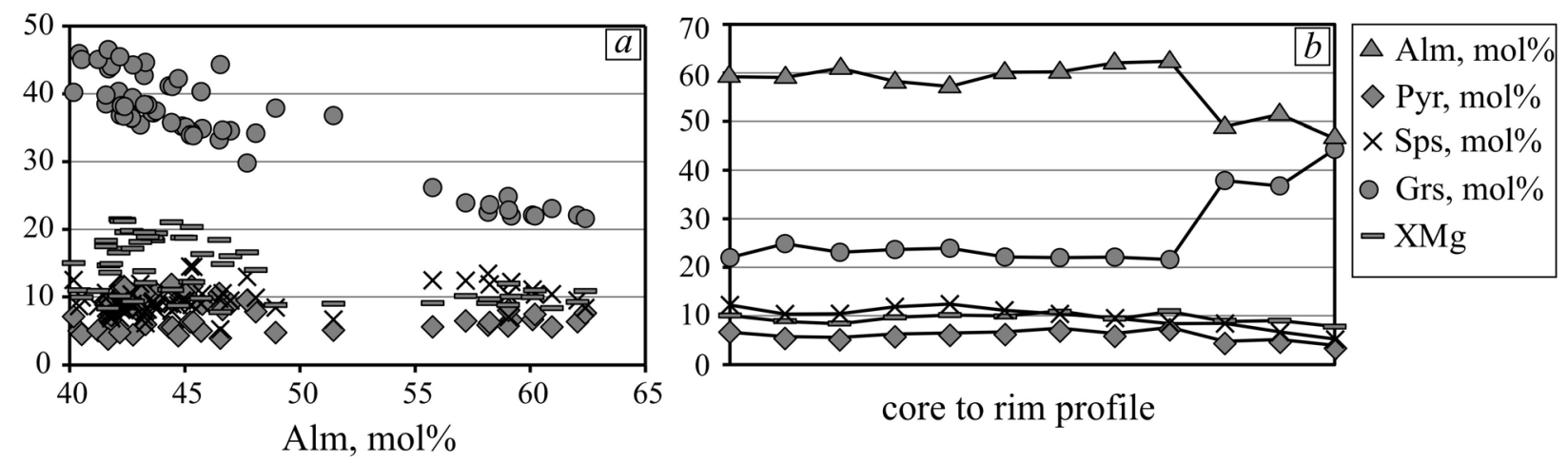

Fig. 9. Garnet compositions in terms of molar fractions: a) plot of almandine (Alm) vs. grossular (Grs), pyrope (Pyr), spessartine (Sps) and $\mathrm{XMg}=\mathrm{Mg} /(\mathrm{Mg}+\mathrm{Fe})$ showing two groups of garnet compositions: almandine-dominated and almandine-grossular; b) chemical core-to-rim profile through garnet porphyroblast passing into aggregates of smaller grains. Note the abrupt change in composition (increase in grossular and decrease in almandine content) due to plagioclase decomposition.

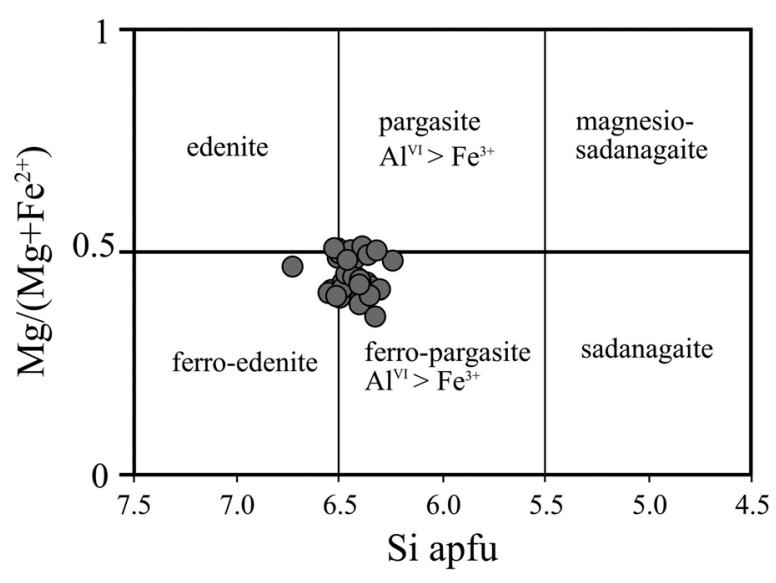

Fig. 10. Amphibole classification diagram of Leake et al. (1997) for calcic amphiboles with $\mathrm{Ca}_{\mathrm{B}} \geq 1.5$, $(\mathrm{Na}+\mathrm{K})_{\mathrm{A}} \geq 0.5$ and $\mathrm{Ti}<0.5$.

in the matrix is always partly transformed in chlorite (Appendix A). Only a small biotite inclusion in clinopyroxene is relatively fresh, with moderate $\mathrm{TiO}_{2}$ content (2.64 wt.\%) and XMg = 55 .

Titanite is the most abundant accessory mineral, forming big euhedral grains (Fig. 5c), but also small clusters. Rutile was observed as inclusions in titanite. The apatite appears as big grains and clusters in the matrix. Euhedral zircon grains are common in the matrix (Fig. 5a). Pyrite, allanite and ilmenite are also common accessory phases (Figs $5 b, 8 c$ ).

The lack of plagioclase in association with porphyroblastic garnet, clinopyroxene or K-feldspar suggests that their crystallization occurred beyond the plagioclase stability field. The expense of plagioclase at higher pressure could explain the extreme variation of grossular content in the garnet and the highest Na content in clinopyroxene and K-feldspar from the porphyroblast association. We assume that garnet-clinopyroxene-K-feldspar is the peak mineral assemblage and formed after the mesocratic matrix, where $\mathrm{Ca}, \mathrm{Al}$ and $\mathrm{K}$ are the main constituents. The amphibole crystalized later, at lower temperature and fluid infiltration. It replaced clinopyroxene and garnet porphyroblasts, but also formed single grains, often close to the deformation fine-grained bands. Biotite is localized in deformation zones and is replaced by chlorite-prehnite-albite. These deformation bands and lenses are the lattermost formed and mark a syn-deformational, fluid-induced mineral crystallization at lower temperature. Only in one thin-section did we observe fine-grained mass of scapolite and carbonate that replace plagioclase.

The petrographic features and mineral chemistry point to multistage metamorphic history of the studied sample. The different parts of the rock are not fully equilibrated, but mineral composition and grain size reflect the changing $\mathrm{P}-\mathrm{T}$ and fluid regime conditions. The presence of higher-grade association and intense fluid-induced mineralization suggests two metamorphic events realized at different $\mathrm{P}-\mathrm{T}$ and fluid regime conditions in the CSZ.

\section{THERMOBAROMETRY AND THERMODYNAMIC MODELING}

In order to determine the pressure-temperature conditions, we used major mineral geothermometry integrated with Zr-in-titanite thermometry and thermodynamic modeling.

Garnet-clinopyroxene thermometer (Krough Ravna, 2000) at $1 \mathrm{GPa}$ yields temperatures of $810^{\circ} \mathrm{C}$ for 
Table 2

Mineral composition of the garnet-clinopyroxene pairs used for geothermometry. Number of analyses corresponds to those in Appendix A

\begin{tabular}{lcccccccc}
\hline Mineral composition & $\mathrm{Grt}_{\mathrm{Alm}}$ & $\mathrm{Grt}_{\mathrm{Grs}}$ & $\mathrm{Grt}_{\mathrm{Pyr}}$ & $\mathrm{Grt}_{\mathrm{Sps}}$ & $\mathrm{Grt}_{\mathrm{XMg}}$ & $\mathrm{Cpx}_{\mathrm{XMg}}$ & at $1 \mathrm{GPa}$ & at $2 \mathrm{GPa}$ \\
\hline $\begin{array}{l}\text { Grt (29), inclusion in } \\
\text { Cpx / Cpx, core (28) }\end{array}$ & 41.81 & 44.05 & 7.30 & 6.83 & 14.87 & 58.53 & $813^{\circ} \mathrm{C}$ & $865^{\circ} \mathrm{C}$ \\
$\begin{array}{l}\text { Grt (25), partly included in } \\
\text { Cpx / Cpx, rim (26) }\end{array}$ & 41.76 & 44.47 & 6.58 & 7.18 & 13.61 & 61.85 & $740{ }^{\circ} \mathrm{C}$ & $789{ }^{\circ} \mathrm{C}$ \\
\hline
\end{tabular}

small garnets (XMg 14.9) included in clinopyroxene cores (XMg 59) and $740{ }^{\circ} \mathrm{C}$ for garnets (XMg 13.6) partly included in the same clinopyroxene rim (XMg 62) (Table 2). At $2 \mathrm{GPa}$, the temperatures are $860^{\circ} \mathrm{C}$ and $790{ }^{\circ} \mathrm{C}$, respectively. These data suggest equilibrium crystallization at high temperature and, despite the fact that no pressure estimates are available, the temperatures obtained correspond to granulite facies metamorphism (O’Brien and Rötzler, 2003).

$\mathrm{Zr}$ content in titanite was determined by LAICP-MS at $8 \mathrm{~Hz}, 35 \mu \mathrm{m}$, standard NIST 610, at the Geological Institute, Bulgarian Academy of Sciences. $\mathrm{Zr}$ was analyzed along the big titanite grains in association with porphyroblasts (Fig. $5 c$ ), as well as in the mesocratic matrix. Zoning in $\mathrm{Zr}$ does not show a regular core-to-rim trend, but the $\mathrm{Zr}$ content generally rises toward the rims of the grains (Appendix B). The Zr-in-titanite thermometer of Hayden et al. (2008), with a $\mathrm{TiO}_{2}$ activity of 1 , yields temperatures in the range from $725^{\circ} \mathrm{C}$ to $810{ }^{\circ} \mathrm{C}$ at $1 \mathrm{GPa}$ pressure. The average temperature is $769 \pm 17^{\circ} \mathrm{C}$ (at $1 \mathrm{GPa}$ ), $826 \pm 18{ }^{\circ} \mathrm{C}$ (at $1.5 \mathrm{GPa}$ ) and $884 \pm$ $19{ }^{\circ} \mathrm{C}$ (at $2 \mathrm{GPa}$ ).

\section{Thermodynamic modeling of $\mathbf{P}-\mathbf{T}$ conditions}

In order to test our petrographic observations on the evolution of the "dry" matrix composition of the porphyroblastic association beyond the plagioclase stability field, we calculated P-T pseudosections based on matrix whole-rock chemical composition. During the preparation of the sample, we picked material only from the mesocratic matrix, avoiding the porphyroblasts, amphibole and deformation zones and lenses. The wet chemical analysis was performed at the Chemical Laboratory of the Faculty of Geology and Geography (Sofia University), with water content less than 1 wt.\% (0.8 wt.\% LOI). The stability of the particular mineral assemblages was modeled using Perple_X thermodynamic software set (Connolly, 2009; version 6.8.8) with the internally consistent thermodynamic data set of Holland and Powell (1998, revised in 2004, hp04ver. dat). Solid-solution models for garnet (White et al., 2007), clinopyroxene (Holland and Powell, 1996), plagioclase (Newton et al., 1980) and sanidine (Thompson and Hovis, 1979) were used. The pseudosection was calculated in the system $\mathrm{Na}_{2} \mathrm{O}-\mathrm{CaO}-$ $\mathrm{K}_{2} \mathrm{O}-\mathrm{FeO}-\mathrm{MgO}-\mathrm{MnO}-\mathrm{Al}_{2} \mathrm{O}_{3}-\mathrm{SiO}_{2}-\mathrm{TiO}_{2}-\mathrm{H}_{2} \mathrm{O}$ (NCKFMMnASTH). The molar content of $\mathrm{CaO}$ in the sample was lowered by the amount necessary for formation of apatite from the analyzed $\mathrm{P}_{2} \mathrm{O}_{5}$ content (0.23 wt.\%), and the used composition is given in Fig. 11. We ran the calculation without saturated compound or phase. For simplicity of the diagram, white micas were excluded as possible phases, as they were not observed in any part of the sample. Melt was included as possible phase.

In the simplified model in this study, we used the analyzed water content (0.8 wt.\%), although in many cases the minerals in the matrix are dry: plagio clase, K-feldspar, clinopyroxene and quartz. Only the minor amount of epidote could explain some water content in the matrix. It is worth noting that in the material used for analysis retrogressed zones were included. On the calculated pseudosection, four phases are "in excess" (present in every field of the diagram): garnet, clinopyroxene, K-feldspar and quartz (Fig. 11). The garnet-free assemblage of the matrix is not present on the pseudosection, but the garnet's modal volume bellow $0.7 \mathrm{GPa}$ is less than 3 vol.\% and increases to 13 vol.\% at high pressure and lower temperature (Fig. 12a). Water fluid is present in all fields, except one in the top left-hand corner of the figure, but its quantity is very low ( $<0.01$ vol.\%). Plagioclase is unstable above 1.2-1.5 GPa and its composition changes quickly at higher pressure (Fig. 12e, f). The stability field of the observed granulite facies assemblage of garnet-K-feldspar-clinopyroxene-quartz is above 1.2-1.5 $\mathrm{GPa}$ and in wide temperature range from $600{ }^{\circ} \mathrm{C}$ to $1000{ }^{\circ} \mathrm{C}$. The quantity of K-feldspar in the high-pressure part of the plot varies insignificantly, while the volume of clinopyroxene increases at higher temperature (Fig. 12b, c). In the same stability field is also present a minor amount of zoisite 


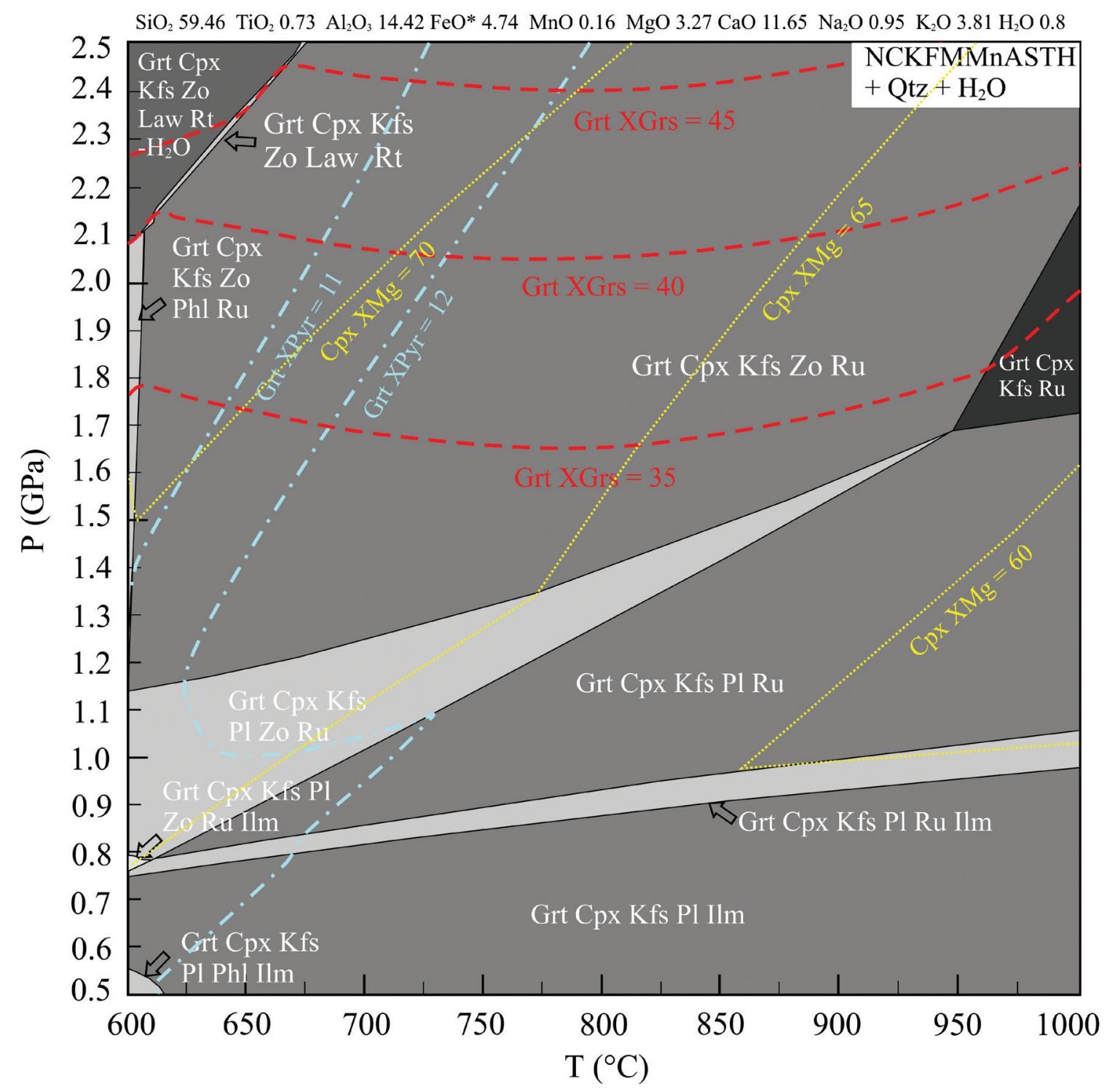

Fig. 11. $\mathrm{P}-\mathrm{T}$ diagram calculated from the bulk matrix composition, showing the stability fields of mineral assemblages. The Grt XGrs $=\mathrm{Ca} /(\mathrm{Ca}+\mathrm{Fe}+\mathrm{Mg}+\mathrm{Mn})$ and $\mathrm{Grt} \mathrm{XFe}=\mathrm{Fe} /(\mathrm{Mg}+\mathrm{Fe})$ ratios of garnet composition are shown as isopleths. Abbreviations: Grt: garnet; Cpx: clinopyroxene; Kfs: K-feldspar; Pl: plagioclase; Qtz: quartz; Zo: zoisite; Ky: kyanite; Phl: phlogopite; Ru: rutile; Ilm: ilmenite.

( $<14$ vol.\%) and its quantity is temperature-dependant (Fig. 12d). The accessory phase is rutile. In the high-pressure and low-temperature part of the figure, lawsonite is present. For garnet composition, we used pyrope and grossular isopleths as almandine and spessartine compounds remain almost unchanged as pyrope increases. The maximum values of pyrope (XPyr $=12)$ correlate with lower grossular content (XGrs = 35-40; Fig. 9) and intersect at $\sim 1.8-2.1 \mathrm{GPa}$ and $c a .700{ }^{\circ} \mathrm{C}$. The temperature is lower than the average temperatures obtained from the $\mathrm{Zr}$-in-titanite $\left(884^{\circ} \mathrm{C}\right)$ and clinopyroxene-garnet $\left(790-860^{\circ} \mathrm{C}\right)$ thermometry for $2 \mathrm{GPa}$. The isopleths of maximum XMg in clinopyroxene $(\mathrm{XMg}=65)$ intersects with the same grossular content in garnet $(\mathrm{XGrs}=35-40)$ at temperature $\mathrm{ca} .850^{\circ} \mathrm{C}$.

The proposed simplified thermodynamic model, although imperfect, outlined some important inferences: a) the upper pressure limits of the plagioclase stability field at $1.2-1.5 \mathrm{GPa}$ and $650-950^{\circ} \mathrm{C}$; b) the composition of plagioclase changes quickly with rising pressure and correlates very well with the petrography and the observed variation in plagioclase composition; c) not all garnet compounds 

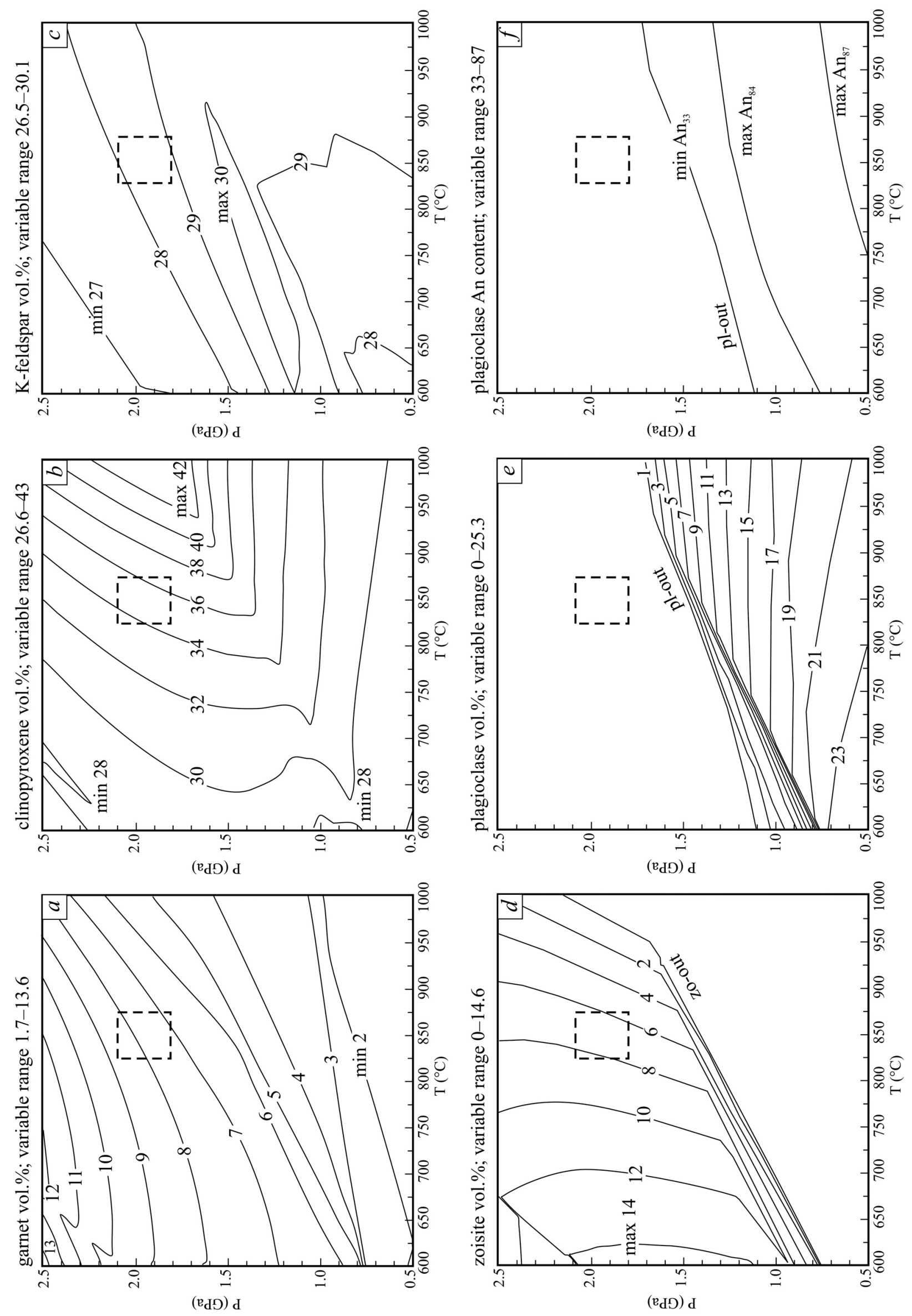
Fig. 12. P-T diagrams showing the modal proportion of garnet (a), clinopyroxene $(b)$, K-feldspar (c), zoisite $(d)$ and plagioclase (e), expressed in vol.\%, and compositional isopleths of anorthite component in plagioclase $(f)$ calculated in the same composition and $\mathrm{P}-\mathrm{T}$ range as in Fig. 11. Dashed rectangles correspond to the estimated $\mathrm{P}-\mathrm{T}$ peak conditions.

could be used successfully in the model, as they change unsystematically due to abrupt change in the grossular content; it seems that pyrope and grossular are most appropriate; d) the jadeite compound in clinopyroxene and albite in K-feldspar vary significantly, controlled by the availability of the compounds during the decomposition of plagioclase; we used the maximum XMg in clinopyroxene and the temperatures correspond to those from accessory titanite and conventional thermometry; e) the matrix composition could produce the observed peak assemblage, but the model could be further refined by using compositions estimated from minerals in different zones.

Having in mind all these points from the thermodynamic model and Zr-in-titanite and conventional clinopyroxene-garnet thermometry, we accept that the peak mineral assemblage of garnet-clinopyroxene-K-feldspar crystallized above the stability field of plagioclase, at pressures of $\sim 1.8-2.1 \mathrm{GPa}$ and temperature of $\sim 850{ }^{\circ} \mathrm{C}$, in the high-pressure (HP) granulite field, and is similar to previously reported data for rocks in the CSZ (Georgieva et al., 2007, 2011; Cherneva et al. 2008).

\section{DISCUSSION AND CONCLUSIONS}

The variegated rocks from the CSZ give a good opportunity to reconstruct the metamorphic history of the complex. Besides the attractive diamondbearing garnet-kyanite gneisses, the petrography, geochemistry and geochronology of the other rock types (e.g., pure and impure marbles, HP melts, metabasites, ultramafic and eclogite boudins) could contribute to our understanding of the origin and metamorphic evolution of the complex. Among the rocks in the CSZ, the studied garnet-clinopyroxene-K-feldspar granulites are the most exotic and their petrology is discussed in details in this paper for the first time.

Petrographic observations reveal a texturally complex rock with matrix association, intergrowths of porphyroblasts and zones of high deformation. The boundaries among the mineral associations are not sharp and the different parts of the sample are not fully equilibrated at changing $\mathrm{P}-\mathrm{T}$ and fluid regime conditions. We identify a peak assemblage of garnet-clinopyroxene-K-feldspar in places with little or absent plagioclase, together with minor quartz and accessory titanite. The P-T conditions (1.8-2.1 $\mathrm{GPa}$ and $850^{\circ} \mathrm{C}$ ), estimated by clinopyroxene-garnet and Zr-in-titanite thermometry and Perple_X modeling of the matrix composition, correspond to HP granulite facies beyond the plagioclase stability field.

The garnet-clinopyroxene-K-feldspar mineral assemblage is not common for granulites. Garnetclinopyroxene-ternary feldspar granulites have been reported from the Bohemian massif (Racek et al., 2008; Štípská et al., 2014). The textures in the granulite are not fully equilibrated and are interpreted as magmatic relicts reworked by metamorphic processes. Similar intermediate granulites from the Bohemian massif were formed by mixing of eclogite and felsic granulite gneisses (Štípská et al., 2014). Non-equilibrated textures have also been described in eclogite boudins from the Arda Unit, where K-feldspar-clinopyroxene-Mg-rich garnet associates with plagioclase-clinopyroxene symplectites and form during the decompression (Machev and Kolcheva, 2012). The presence of Kfeldspar is explained by infiltration of melts from the adjacent migmatic gneisses. Garnet-clinopyroxene-K-feldspar-quartz develops as hydrothermal alteration on garnet-free calc-silicate rocks (calcite-clinopyroxene-K-feldspar-anorthite-quartz) during sulfide mineralization (Dziggel et al., 2009). The garnet grows from the hydrothermal fluid, but calcite is present in the matrix or as inclusion in garnet and the alteration is controled by the sulfide mineralization zone.

The few outcrops and scarce field observations do not give evidence of rock mixing or melt and fluid infiltration for the studied sample. The spatial relation with marbles would suggest metasomatic processes and formation of reaction zones or metamorphic scarns. Nevertheless, the carbonate minerals in the studied granulite are very rare and the metasomatic zone would be very thick and homoge- 
neous. The decarbonization reactions, the presence of $\mathrm{CO}_{2}$ in the fluids and the metasomatic influence from adjacent silicate rocks could be further tested by thermodynamic models. Metasomatic alteration could be a good explanation for the formation of the matrix assemblage of plagioclase-K-feldsparclinopyroxene-quartz also because the extremely high anorthite content in plagioclase and the $\mathrm{CO}_{2}$ bearing fluids could expand the stability fields of "dry" minerals.

Mixing of rocks with different composition and the generated from them melts are another possible scenario. The infiltration of HP leucogranitic melts with peritectic garnet-K-feldspar-kyanite from the CSZ (Cherneva et al., 2008; Georgieva et al., 2011; Petrik et al., 2016) seems likely, as garnetkyanite gneisses do not crop out in the quarry and the shield effect of marbles would prevent significant melt migration. However, interaction between the migmatic biotite gneisses and metabasic rocks present in the quarry should also be taken into consideration.

Despite all these considerations, the question about the origin and nature of the matrix mineral association and the processes that could change its composition remains open. The crystallization of porphyroblasts does not require any metasomatic exchange or the presence of fluid, as the main reaction is at the expense of plagioclase at higher pressure. The fine-grained deformation zones channel the lattermost fluid infiltration, while the matrix and porphyroblast associations are less affected. It seems that the permeability of the rock is low and this allows the preservation of higher-grade metamorphic minerals.

The variegated rocks from the CSZ record at least two metamorphic events and the studied granulite sample confirms this previous observation. Based on the geochronological data for the rocks from the CSZ, we accept that the granulite facies is related to the UHP metamorphic event, rather than being a younger one.

\section{Acknowledgements}

This study was supported by the National Scientific Fund of Bulgaria, project DN 14/15 - 2017. Z. Cherneva is warmly thanked for much-appreciated critical review of the manuscript. L. Metodiev and G. Granchovski are thanked for their editorial help.

APPENDIX A. Representative EMP analyses of minerals. (This file is available online at https:// www.geologica-balcanica.eu/sites/default/files/ supplementary/Georgieva_Geol Balc 48-3 2019 Appendices.rar.)

APPENDIX B. LA-ICP-MS analyses of Zr content in titanite. (This file is available online at https:// www.geologica-balcanica.eu/sites/default/files/ supplementary/Georgieva Geol Balc 48-3 2019 Appendices.rar.)

\section{REFERENCES}

Armbruster T., Bonazzi, P., Akasaka, M., Bermanec, V., Chopin, C., Gieré R., Heuss-Assbichler, S., Liebscher, A., Menchetti, S., Pan Y., Pasero, M. 2006. Recommended nomenclature of epidote-group minerals. European Journal of Mineralogy 18, 551-567.

Brown, M. 2007. Metamorphic conditions in orogenic belts: a record of secular change. International Geology Review 49 (3), 193-234.

Burg, J.-P. 2012. Rhodope: From Mesozoic convergence to Cenozoic extension. Review of petro-structural data in the geochronological frame. In: Skourtsos, E., Lister, G. (Eds), The Geology of Greece. Journal of the Virtual Explorer 42, Electronic Edition, paper 1.

Cherneva, Z., Georgieva, M. 2007. Amphibole-bearing leucosome from the Chepelare area, Central Rhodopes: P-T conditions of melting and crystallization. Geochemistry, Mineralogy and Petrology 45, 79-95.

Cherneva, Z., Georgieva, M., Stancheva, E., Gerdjikov, I. 2008a. High-pressure garnet-bearing migmatites from the
Chepelare area, Central Rhodopes. Geologica Balcanica 37 (1-2), 47-52.

Cherneva, Z., Gerdjikov, I., Gautier, P., Bosse, V., Georgieva, M. 2008b. The assemblage garnet-clinopyroxene-plagioclasequartz in products of melting from the Central Rhodope. Bulgarian Geological Society, National Conference with International Participation “Geosciences 2008”, Abstracts, 39-40.

Collings, D., Savov, I., Maneiro, K., Baxter, E., Harvey, J., Dimitrov, I. 2016. Late Cretaceous UHP metamorphism recorded in kyanite-garnet schists from the Central Rhodope Mountains, Bulgaria. Lithos 246-247, 165-181.

Connolly, J.A.D. 2009. The geodynamic equation of state: what and how. Geochemistry, Geophysics, Geosystems 10, Q10014 DOI:10.1029/2009GC002540.

Didier, A., Bosse, V., Cherneva, Z., Gautier, P., Georgieva, M., Paquette, J.-L., Gerdjikov, I. 2014. Syn-deformation fluidassisted growth of monazite during renewed high-grade metamorphism in metapelites of the Central Rhodope (Bulgaria, Greece). Chemical Geology 381, 206-222. 
Dziggel, A., Wulff, K., Kolb, J., Meyer, F. M., Lahaye, Y. 2009. Significance of oscillatory and bell-shaped growth zoning in hydrothermal garnet: evidence from the Navachab gold deposit, Namibia. Chemical Geology 262, 262-276.

Georgieva, M., Bosse, V., Cherneva, Z., Gautier, P., Gerdjikov, I. Tiepolo, M. 2010. Late-Jurassic granulite facies metamorphism of garnet-bearing metabasic rocks from the Chepelare area, Central Rhodope. Bulgarian Geological Society, National Conference with International Participation “Geosciences 2010”, Abstracts, 31-32.

Georgieva, M., Cherneva, Z., Gerdjikov, I., Stancheva, E. 2010. Metabasic rocks from the Chepelare variegated complex, Central Rhodope massif, Bulgaria - preliminary studies. Geologica Balcanica 39 (1-2), Special Issue, Proceedings of the XIX CBGA Congress, Thessaloniki, 131-132.

Georgieva, M., Bosse, V., Cherneva, Z., Kirilova, M. 2011. Products of HP melting in Chepelare shear zone, Central Rhodope, Bulgaria - petrology, P-T estimates and U-Th- $\mathrm{Pb}$ dating. Bulgarian Geological Society, National Conference with International Participation “Geosciences 2011”, Abstracts, 55-56.

Georgieva, M., Cherneva, Z., Mogessie, A., Stancheva, E. 2007. Garnet-kyanite schists from the Chepelare area, Central Rhodope Mts., Bulgaria: mineral chemistry, thermobarometry and indications for high-pressure melting. Bulgarian Geological Society, National Conference with International Participation “Geosciences 2007”, Abstracts, 97-98.

Gerdjikov, I., Gautier, P., Cherneva, Z., Bosse, V., Ruffet. G. 2010. Late Eocene synmetamorphic thrusting and synorogenic extension across the metamorphic pile of the Bulgarian Central Rhodope. Geologica Balcanica 39 (1-2), Special Issue, Proceedings of the XIX CBGA Congress, Thessaloniki, 132-133.

Holland, T., Powell, R. 1996. Thermodynamics of order-disorder in minerals. 2. Symmetric formalism applied to solid solutions. American Mineralogist 81, 1425-1437.

Holland, T., Powell, R. 1998. An internally consistent thermodynamic data set for phases of petrological interest. Journal of Metamorphic Geology 16, 309-343.

Ivanov, Ž., Moskovski, S., Kolcheva, K., Dimov, D., Klain, L. 1984. Geological structure of the Central Rhodopes. I. Lithostratigraphic subdivision and features of the section of metamorphic rocks in the northern parts of the Central Rhodopes. Geologica Balcanica 14 (1), 3-42 (in Russian).

Ivanov, Ž., Dimov, D., Dobrev, S., Kolkovski, B., Sarov, S. 2000. Structure, Alpine evolution and mineralizations of the Central Rhodopes area (South Bulgaria). Guide to Excursion B, ABCD-GEODE workshop, Borovets, Bulgaria, 50 pp.

Kozhoukharov, D. 1984. Lithostratigraphy of the Precambrian metamorphic from Rhodope Supergroup in the Central Rhodopes. Geologica Balcanica 14 (1), 43-88 (in Russian).
Krough Ravna, E. 2000. The garnet-clinopyroxene $\mathrm{Fe}^{2+}-\mathrm{Mg}$ geothermometer: an updated calibration. Journal of Metamorphic Geology 18, 211-219.

Machev, Ph., Kolcheva, K. 2012. Eclogites from Arda tectonic unit - mineralogy and P-T evolution. The School of Prof. Zhivko Ivanov, International Conference, Sofia, 57-60.

Morimoto, M., Fabries, J., Ferguson, A. K., Ginzburg, I. V., Ross, M., Seifert, F. A., Zussman, J., Aoki, K., Gottardi, G. 1988. Nomenclature of pyroxenes. American Mineralogist 73, 1123-1133.

Newton, R., Charlu, T., Kleppa, O. 1980. Thermochemistry of high structural state plagioclases. Geochimica et Cosmochimica Acta 44, 933-941.

O’Brien, P.J., Rötzler, J. 2003. High-pressure granulites: formation, recovery of peak conditions, and implications for tectonics. Journal of Metamorphic Geology 21, 3-20.

Pattison, D. 2003. Petrogenetic significance of orthopyroxenefree garnet + clinopyroxene + plagioclase \pm quartz-bearing metabasites with respect to the amphibolite and granulite facies. Journal of Metamorphic Geology 21, 21-34.

Petrik, I., Janak, M., Froitzheim, N., Georgiev, N., Yoshida, K., Sasinkov, V., Konečny, A.P., Milovska, S. 2016. Triassic to Early Jurassic (c. $200 \mathrm{Ma}$ ) UHP metamorphism in the Central Rhodopes: evidence from U-Pb-Th dating of monazite in diamond-bearing gneiss from Chepelare (Bulgaria). Journal of Metamorphic Geology 34, 265-291.

Racek, M., Štípská, P., Powell, R. 2008. Garnet-clinopyroxene intermediate granulites in the St. Leonhard massif of the Bohemian Massif: ultrahigh-temperature metamorphism at high pressure or not?. Journal of Metamorphic Geology 26, 253-271.

Sarov, S. 2012. Lithotectonic subdivision of the metamorphic rocks in the area of Rila and Rhodope Mountains - results from geological mapping at scale 1:50 000. The School of Prof. Zhivko Ivanov, International Conference, Sofia, 43-47.

Štípská, P., Powell, R., Racek, M., Lexa, O. 2014. Intermediate granulite produced by transformation of eclogite at a felsic granulite contact, in Blanský les, Bohemian Massif. Journal of Metamorphic Geology 32, 347-370.

Thompson, J. B., Hovis, G. L. 1979. Entropy of mixing in sanidine. American Mineralogist 64, 57-65.

Touret, J., Huizenga, J.M. 2012. Fluid-assisted granulite metamorphism: A continental journey. Gondwana Research 21, 224-235.

Wawrzenitz, N., Krohe, A., Baziotis, I., Mposkos, E., Kylander-Clark, A., Romer, R. 2015. LASS U-Th-Pb monazite and rutile geochronology of felsic high-pressure granulites (Rhodope, N Greece): Effects of fluid, deformation and metamorphic reactions in local subsystems. Lithos 232, 266-285.

White, R. W., Powell, R., Holland, T. J. B. 2007. Progress relating to calculation of partial melting equilibria for metapelites. Journal of Metamorphic Geology 25, 511-527. 